\title{
HYDROGEOLOGY OF THE GÖKPINAR KARST SPRINGS, SIVAS, TURKEY
}

\author{
HIDROGEOLOGIJA KRAŠKIH IZVIROV GÖKPINAR, \\ SIVAS, TURČIJA
}

\author{
Fikret KAÇAROĞLU ${ }^{1}$
}

\begin{abstract}
UDC 556.36:551.44(560)

Fikret Kaçaroğlu: Hydrogeology of the Gökpinar karst springs, Sivas, Turkey

Gökpınar karst springs are located $8 \mathrm{~km}$ to the south of the Gürün district centre, Sivas, Turkey. The springs have two main outlets (Gökpınar-1 and Gökpınar-2) and outflow from Jurassic-Cretaceous Yüceyurt formation (limestone). The total discharge of the springs ranges between 4.5 and $7.8 \mathrm{~m}^{3} / \mathrm{s}$. The study area is formed of allocthonous and autocthonous lithological units whose ages range from Upper Devonian to Quaternary. These lithologies are mostly formed of limestones. Yüceyurt formation (limestone), from which Gökpınar karst springs outflow, constitute the main aquifer in the study area and is karstified. The unit has a well developed karst system comprising karren, dolines, ponors, underground channels and caves. The recession (discharge) analysis of the Gökpınar springs was carried out and the storage capacities and discharge (recession) coefficients of the Gökpınar-1 and Gökpınar-2 springs were calculated as $141 \times 10^{6} \mathrm{~m}^{3}$ and $98 \times 10^{6} \mathrm{~m}^{3}$, and $2.71 \times 10^{-3} \mathrm{day}^{-1}$ and $2.98 \times 10^{-3} \mathrm{day}^{-1}$, respectively. The storage capacities and discharge (recession) coefficients obtained suggest that the karst aquifer (Yüceyurt limestone) has large storage capacity, and drainage occurs very slow. The major cations in the study area waters are $\mathrm{Ca}^{2+}$ and $\mathrm{Mg}^{2+}$, and anion is $\mathrm{HCO}_{3}^{-}$. The waters are calcium bicarbonate type. Some of the water chemistry parameters of the Gökpınar springs range as follows: $\mathrm{T}=10.8-11.1^{\circ} \mathrm{C}, \mathrm{pH}=7.65-7.95$, $\mathrm{EC}=270-310 \mu \mathrm{S} / \mathrm{cm}, \mathrm{TDS}=170-200 \mathrm{mg} / \mathrm{L}, \mathrm{Ca}^{2+}=40.0-54.0 \mathrm{mg} / \mathrm{L}$, $\mathrm{Mg}^{2+}=4.5-10.0 \mathrm{mg} / \mathrm{L}, \mathrm{HCO}_{3}^{-}=144.0-158.0 \mathrm{mg} / \mathrm{L}$. Temperature, EC, TDS, and $\mathrm{Ca}^{2+}$ and $\mathrm{HCO}_{3}^{-}$concentrations of the Gökpınar springs did not show significant variations during the study period.
\end{abstract}

Keywords: hydrogeology, karst, groundwater, Gökpınar springs, Sivas.
Izvleček UDK 556.36:551.44(560) Fikret Kaçaroğlu: Hidrogeologija kraških izvirov Gökpinar, Sivas, Turčija

Kraški izviri Gökpınar se nahajajo 8 km južno od regijskega središča Gürün, Sivas, Turčija. Voda izvira iz dveh glavnih izvirov (Gökpınar 1 in Gökpınar 2) in izteka iz jursko kredne Yüceyurt formacije (apnenec). Skupni pretoki nihajo med 4,5 in 7,8 $\mathrm{m}^{3} / \mathrm{s}$. Prispevno območje pokriva alohtone in avtohtone litološke enote, katerih starost sega od zgornje devonskih do kvartarnih kamnin, večinoma apnencev. Formacija Yüceyurt (apnenec) sestavlja glavni vodonosni sistem in je močno zakrasela. Območje prekrivajo številne škraplje, vrtače, ponori, podzemni kanali in jame. $\mathrm{V}$ prispevku je bila izvedena analiza zmanjševanja pretoka na izvirih Gökpınar, izračunani sta bila količnika uskladiščenja in upadanja pretoka obeh glavnih izvirov. Količnik uskladiščenja je $141 \times 10^{6} \mathrm{~m}^{3}$ oziroma $98 \times 10^{6} \mathrm{~m}^{3}$, količnik upadanja pretoka pa $2.71 \times 10^{-3} \mathrm{dan}^{-1}$ oziroma $2.98 \times 10^{-3} \mathrm{dan}^{-1}$. Dobljeni rezultati kažejo, da ima obravnavani vodonosnik Yüceyurtskega apnenca veliko zmogljivost uskladiščenja in zato je odvodnjavanje precej počasno. Glavni kationi v vodah na obravnavanem območju so $\mathrm{Ca}^{2+}$ in $\mathrm{Mg}^{2+}$, med anioni pa prevladuje $\mathrm{HCO}_{3}^{-}$. Vode so kalcij-bikarbonatnega tipa. Nekateri kemijski parametri v vodah izvirov Gökpınar se gibljejo med naslednjimi vrednostmi: $\mathrm{T}=10.8-11.1^{\circ} \mathrm{C}, \mathrm{pH}=7.65-7.95$, $\mathrm{EC}=270-310 \mu \mathrm{S} / \mathrm{cm}, \mathrm{TDS}=170-200 \mathrm{mg} / \mathrm{L}, \mathrm{Ca}^{2+}=40.0-54.0 \mathrm{mg} / \mathrm{L}$, $\mathrm{Mg}^{2+}=4.5-10.0 \mathrm{mg} / \mathrm{L}, \mathrm{HCO}_{3}^{-}=144.0-158.0 \mathrm{mg} / \mathrm{L}$. Temperatura, $\mathrm{EC}, \mathrm{TDS}, \mathrm{Ca}^{2+}$ in $\mathrm{HCO}_{3}^{-}$koncentracije niso v času opazovanja pokazale značilnih variacij.

Ključne besede: hidrogeologija, kras, podzemna voda, izviri Gökpınar, Sivas.

\footnotetext{
${ }^{1}$ Muğla Sitkı Koçman University, Department of Geological Engineering, TR-48000 Muğla, Turkey, e-mail: fkacaroglu@mu.edu.tr Received/Prejeto: 29.3.2010
} 


\section{INTRODUCTION}

Karst terrains in the world are mostly composed of carbonate rocks. About one third of Turkey is covered by carbonate rocks, and most of these rocks are karstified. Karst groundwater is a major water resource for many settlements (e.g. Antalya, İskenderun) in the karstic regions of Turkey (Kaçaroğlu 1999). Carbonate rocks (limestone, dolomitic limestone) cover a large area in the vicinity of Gürün, south of Sivas, Turkey. Karstification has developed in most of these rocks. High-yield karst springs outflow from these karstified lithologies. Karstification also occurs in the gypsum in the region extending from the west to the east of Sivas, Turkey, and there are some large capacity gypsum karst springs (Kaçaroğlu et al. 1997, 2001).

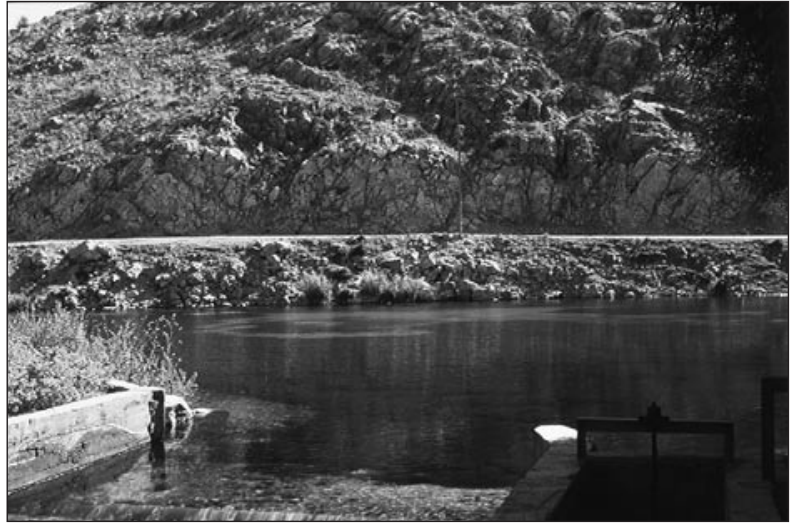

Fig. 3: Gökpınar-2 spring (Photo: F. Kaçaroğlu).

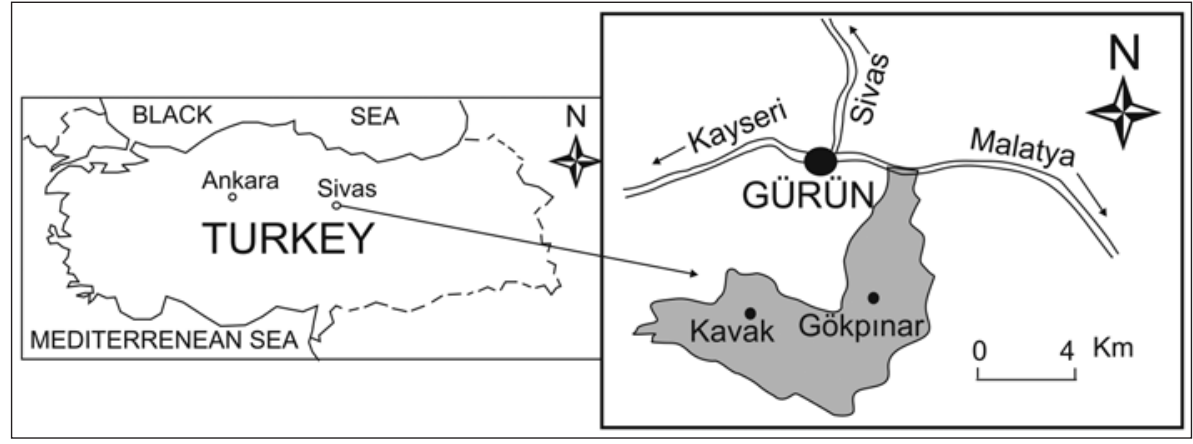

Fig. 1: Location map of the study area.

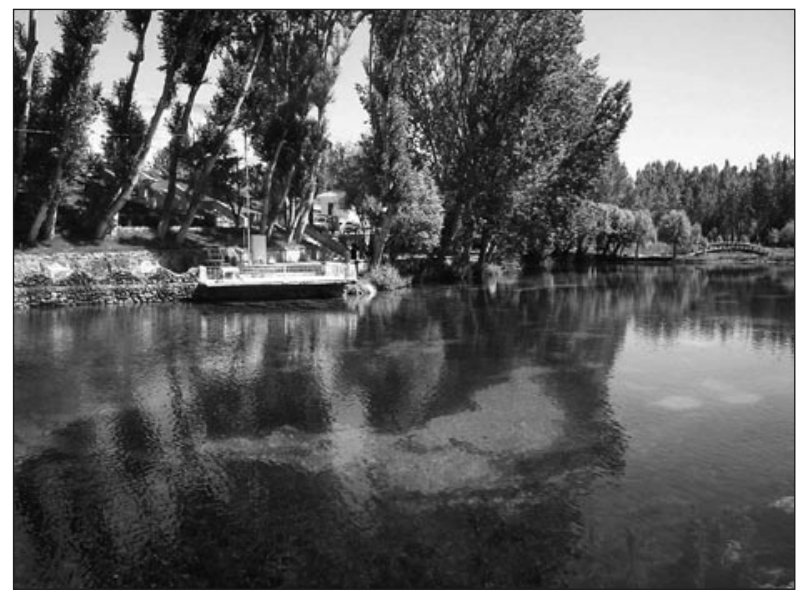

Fig. 2: Gökpınar-1 spring (Photo: F. Kaçaroğlu).

Gökpınar karst springs are located $8 \mathrm{~km}$ to the south of Gürün district centre, Sivas, Turkey (Fig. 1). The springs discharge the groundwater in the karstified Jurassic-Cretaceous Yüceyurt formation (limestone) and have two main outlets. Gökpınar springs (Gökpınar-1 and Gökpınar-2) form two ponds at the discharge points (Figs. $2 \& 3$ ).
The water is used for fish production, power (electricity) generation and irrigation. This study was conducted to identify the hydrogeological and hydrogeochemical properties of the Gökpinar karst springs and karstic features of the study area. The study is the first hydrogeological investigation conducted on Gökpınar karst springs.

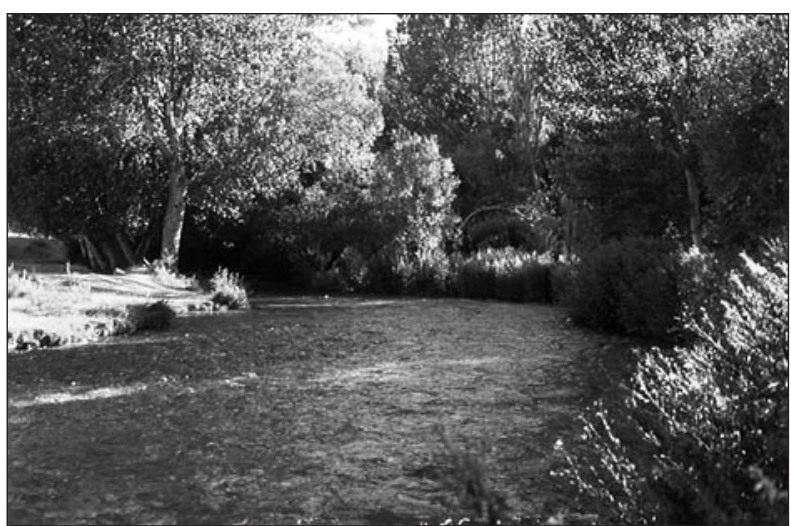

Fig. 4: Gökpınar stream (downstream of the Gökpınar springs, GD-1) (Photo: F. Kaçaroğlu).

The study area covers an area of about $200 \mathrm{~km}^{2}$ which is drained by Gökpınar stream. Gökpınar stream (Fig. 4), mainly fed by Gökpınar karst springs, discharges into Tohma river (Fig. 5) which is a tributary of the Euphrates river. The Euphrates river and its tributaries constitute one of the largest trans-boundary river system in the Middle East and lie in Turkey, Syria and Iraq. 


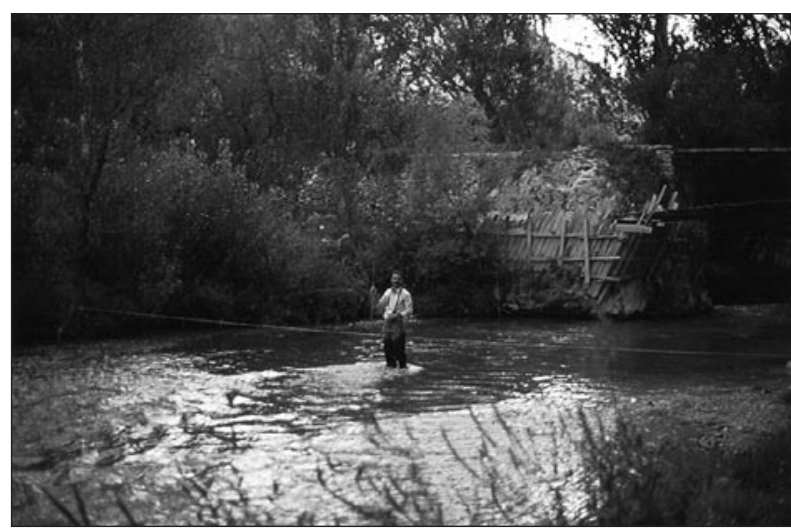

Fig. 5: Tohma river (upstream of the Gökpinar stream connection, TÇ-1) (Photo: F. Kaçaroğlu).
Field observations and mapping, discharge measurement on the streams and springs, water sampling and analyses were performed in order to achieve the purposes of the study. The flow measurement of the springs and streams were carried out by means of current meter. Temperature (T), $\mathrm{pH}$, electrical conductivity (EC), and total dissolved solids (TDS) of the waters were measured at the time of the sample collection using portable (field-type) instruments. EC values were reported at $25^{\circ} \mathrm{C}$. The measurement and analysis procedures given by APHA-AWWA-WPCF (1995) and Hem (1985) were followed during the field and laboratory work. The field work of the study were carried out between August 1995 and October 1996.

\section{GEOLOGY}

The study area is located within the Eastern Taurid Belt (Kurtman 1978; Atabey et al. 1994). In the area allochtonous and autochtonous sedimentary, ophiolitic and volcanic rocks crop out. The geological ages of these rocks range from Upper Devonian to Quaternary (Fig. 6). The geological setting of the area is described in the following paragraphs based on the studies of Kurtman (1978), Atabey $(1993,1996)$ and Atabey et al. (1994).

\section{STRATIGRAPHY}

Allochtonous lithological units (Fig. 6) consist of Munzur limestone (Triassic) and Pınarbaşı ophiolite (Jurassic-
Cretaceous), whereas autocthonous units are Gümüşali (Upper Devonian), Yüceyurt (Jurassic-Cretaceous), Demiroluk (Eocene), Gövdelidağ (Upper Eocene-Lower Miocene), Gürün (Miocene) formations and Alluvium (Quaternary).

Munzur limestone (Mzm) is exposed in the eastern part of the area, and consists of medium-thick bedded, gray-white, yellowish coloured, fractured, partially karstified limestone. The thickness of the unit ranges between 400-750 m. Pınarbaşı ophiolite (Kp) crops out in a small area in the east, and formed of serpantine, serpantinized peridotite, piroxenite, harzburgite, dunite and gabro.

Gümüşali formation (Dg) crops out in the eastern part of the area. It consists of algae, gastropoda, echinide, brachiopoda containing thin-medium bedded limestone, and alternating shale, mudstone and thin bedded sandstone. The thickness of the formation ranges between 200-250 m.

Yüceyurt formation (Jky) covers the largest part of the area. It comprises medium-thick bedded, greywhite, yellowish coloured limestone and dolomitic limestone at lower and middle parts of the sequence. The upper part of the unit consists of partially massive,

Fig. 6: Hydrogeological map of the study area (modified from Atabey et al. 1994 and Kaçaroğlu 2006). 
white and pinkish coloured limestone. The unit is densely fractured, jointed and karstified. The thickness of the formation ranges between $400-1,100 \mathrm{~m}$. The unit overlies Gümüşali formation and is overlain by Demiroluk formation unconformably.

Demiroluk formation (Td) is exposed at the central and southern parts of the study area. It comprises conglomerate, calcarenite, sandstone, limestone, marl and clayey limestone. The formation is divided into two members (Atabey et al. 1994) as Arpaçukuru member (Tda) and Başören member (Tdb). Arpaçukuru member consists of thick bedded conglomerate, calcarenite, thick bedded and massive limestone. The thickness of the member ranges between 50-200 m. Başören member is formed of alternating grey-greenish marl, thin layered calcarenite, clayey limestone, and very thick bedded $(2-3 \mathrm{~m})$ calcarenite and sandstone. The thickness of the member ranges between $200-400 \mathrm{~m}$.

Gövdelidağ formation (Tgd) crops out in a small area at the southeast of the study area. The unit is formed of red, thick bedded and massive conglomerate and interlayers of thick bedded $(0.5-1.0 \mathrm{~m})$ sandstone, and brown, yellow coloured mudstone. The thickness of the formation ranges between 200-350 m. The unit overlies Demiroluk formation and overlain by Gürün formation unconformably.

Gürün formation (Tg), which was named by Kurtman (1978) is exposed at the north and northwest of the study area. The unit consists from the bottom to the top of conglomerate, sandstone, calcarenite, marl, mudstone, tuf, tufite, marl interlayered thin layered clayey limestone and medium-thick bedded or massive limestone (Atabey et al. 1994). This rock sequence is crossed by volcanic rocks or contain their interlayers at some localities. These volcanic rocks comprise tracky andesite, andesite, tuf, aglomerate and lava, and were identified as Karadağ member (Tgk) by Kurtman (1978). Tracky andesite has columnar and jointed structure.

Alluvium (Qal) is exposed along the Tohma river and Gökpınar stream valleys. It consists of loose gravel, sand, silt, and clay. Locally clay lenses and cross-bedding is present in the alluvium.

\section{TECTONICS}

The study area is located in the Taurid Tectonic Belt (Kurtman 1978). The geological evolution of the region was completed between Upper Devonian and Quaternary. Pınarbaşı ophiolite replaced over the carbonate rocks (Munzur limestone) during pre-Maestrichtian. Due to the compressional regime which initiated in Upper Paleocene period folds, overthrusts, strike slip and normal faults have developed (Fig. 6). Munzur limestone thrusted over autochtonous lithological units. The folds (anticlines and synclines) developed in Gürün formation strike in NE-SW direction. In Miocene N-S directed Suçatı strike-slip fault formed, and crossed pre-Pliocene aged rocks (Atabey et al. 1994). The rocks in the study area have gained fractured and jointed character at different degrees depending on the lithological and physical properties. Jointed structure is apparent especially in limestones.

\section{KARST HYDROGEOLOGY}

\section{KARST FEATURES}

Karst areas are characterized by the occurrence of the various type and size karst features and karst landforms. In the study area (Fig. 6), small scale solution sculpture and large scale karst landforms and features have developed mostly in the Yüceyurt limestone. Small scale solution sculpture consists of microkarren, karren, solution pits and solution pans. Large scale karst landforms in the study area are dolines (sinkholes), ponors (swallow holes), and closed depressions. Some caves were also observed in the study area.

Karren are the most developed karst landforms in the study area. The dimensions of the karren range in general from a few centimeters up to 10 meters in length, and from a few centimeters to 1 meter in width and depth. Some karren chanels are filled by excess soil. They are dominantly of "rundkarren" type (Bögli 1980; Ford \& Williams 2007) which have rounded cross section.

On the Yüceyurt formation which mostly consists of thick bedded or massive limestone, karren form limestone pavements in some bare areas. The dimensions of the pavement areas in the study area extend up to a few hundred meters. Limestone pavements develop best upon thick to massive bedded strata where strata are flatlying or gently dipping (Ford \& Williams 2007). Alpine relief and climate particularly encourages bare-pavement karst, with joint enlargement (kluftkarren) and little soil cover (LaFleur 1999).

Solution pits which are among the observed karst landforms in the study area have circular, elliptical or irregular plan view, and their diameter range from a few centimetres to several decimetres. Some pits are aligned, 
and located along the joints. Solution pans have flat or nearly flat bottoms, and are generally observed on bare rock.

Dolines are among the karst landforms that give karst topography its particular character, and are caused by dissolution, collapse, suffosion, or subsidence processes. In the study area dolines are widely distributed karst landforms. The dolines in the study area which were probably caused by dissolution or collapse, are mostly distributed in the south and west parts of the area at high altitudes, and often follow structural trends and lineaments. They are usually circular to subcircular in plan view and have diameters ranging from a few meters to some hundred meters.

Ponors (swallow holes) are the places where the water from allogenic sources inflows into karst aquifer and make important contribution to the karst groundwater recharge process. The water goes underground via a ponor as a sinking stream, concentrated recharge, or from ponded water. Ponors observed in the study area are generally located at the bottom or along the periphery of the closed depressions, along the fault and fracture zones, and along the stream beds. They have irregular or subcircular shape and the dimensions reach up to a few meters.

Large scale closed depressions are scarse in the study area in comparison to the number of dolines. Closed depressions tend to be broad and shallow. Their length in the study area reach up to several hundred meters.

\section{KARST SPRINGS}

The groundwater flow system in the karst aquifer of the Gökpınar springs (Yüceyurt formation) is characterized by relatively uniform flow and reasonably uniformity of the hydrochemistry of the springs. In the study area two large capacity karst springs, named Gökpınar-1 (GK-1)
(Fig. 2) and Gökpınar-2 (GK-2) (Fig. 3) springs, outflow from the Jurassic-Cretaceous Yüceyurt formation (Fig. 6 \& Tab. 1). These springs constitute two main discharge points of the karstic aquifer, and are located on the boundary of the Yüceyurt and Gürün formations. There are also nine low yield ( 0.5 to $3.0 \mathrm{~L} / \mathrm{s})$ springs (Tab. 1) in the study area outflowing from Yüceyurt and Gürün formations (Kaçaroğlu 2001, 2006). Karst springs commonly appear at the contact between a carbonate-rock massif and low-permeability layers (Bonacci 2001).

Gökpınar-1 spring (Fig. 2) is located in the east part of the study area. It outflows through the bottom of a funnel-shaped depression (approximately $100 \mathrm{~m}$ in length, $40 \mathrm{~m}$ in width), forms a "rise pond" (White 2002), with a maximum depth of $15 \mathrm{~m}$, and discharges its water into Gökpınar stream via a channel. Discharge of the spring ranges between $2,415-4,425 \mathrm{~m}^{3} / \mathrm{s}$ (Tab. 1).

Gökpınar-2 spring (Fig. 3) is located about $100 \mathrm{~m}$ to the west of the Gökpinar-1 spring and issues from the limestone aquifer through solution channels. The spring forms a pond (approximately $40 \mathrm{~m}$ in length, $15 \mathrm{~m}$ in width, and maximum depth is $2 \mathrm{~m}$ ), and discharges its water into Gökpınar stream via a channel. Discharge of the spring ranges $2,175-3,395 \mathrm{~m}^{3} / \mathrm{s}$.

The discharges of the Gökpınar-1 and Gökpınar-2 springs does not have considerable variations between wet and dry months. This situation may be attributed to slow response character of the karst aquifer (Yüceyurt formation). In slow response aquifers the throughput time is sufficiently long to completely flatten the individual hydrographs, and a broad rise and fall relating to wet and dry seasons is observed (White 1999). Hershey et al. (2010) claimed that large and consistent spring discharges suggest a supporting groundwater system that is recharged over a large area where natural small-scale variations in recharge are smoothed.

Tab. 1: Springs in the study area.

\begin{tabular}{|c|c|c|c|c|c|}
\hline $\begin{array}{l}\text { Spring } \\
\text { no. }\end{array}$ & Name of the spring & Aquifer lithology (formation) & $\begin{array}{c}\text { Altitude a.s.l. } \\
(m)\end{array}$ & $\begin{array}{c}\text { Discharge } \\
(\mathrm{L} / \mathrm{s})\end{array}$ & $\begin{array}{c}\text { Date of } \\
\text { measurement }\end{array}$ \\
\hline GK-1 & Gökpınar-1 & Limestone (Yüceyurt fm.) & 1,445 & $\begin{array}{l}2,415 \\
4,425\end{array}$ & $\begin{array}{l}22.04 .1996 \\
16.07 .1996\end{array}$ \\
\hline GK-2 & Gökpınar-2 & Limestone (Yüceyurt fm.) & 1,450 & $\begin{array}{l}2,176 \\
3,395\end{array}$ & $\begin{array}{l}31.10 .1995 \\
16.07 .1996\end{array}$ \\
\hline GK-3 & Serkiz Dere & Limestone (Gürün fm) & 1,920 & 1.0 & 04.08 .1995 \\
\hline GK-4 & Kale Dere & Limestone - Clayey limestone (Gürün fm.) & 1,890 & 3.0 & 04.08 .1995 \\
\hline GK-5 & Büyük çeşme (Kavak) & Clayey limestone (Gürün fm.) & 1,820 & 2.0 & 04.08 .1995 \\
\hline GK-6 & Körpınar & Limestone (Gürün fm) & 1,880 & 2.0 & 04.08.1995 \\
\hline GK-7 & Dönükpınar & Limestone (Gürün fm.) & 1,870 & 0.5 & 04.08 .1995 \\
\hline GK-8 & Küçükyazılı & Limestone (Gürün fm.) & 1,880 & 1.0 & 04.08.1995 \\
\hline GK-9 & Halacoğlu & Limestone (Gürün fm.) & 1,850 & 0.5 & 04.08 .1995 \\
\hline GK-10 & Akpınar & Limestone (Gürün fm.) & 1,820 & 0.5 & 04.08 .1995 \\
\hline GK-11 & Yelken & Limestone (Yüceyurt fm.) & 1,650 & 1.0 & 04.08.1995 \\
\hline
\end{tabular}


A parallel trend exists between spring discharges and temperatures (Fig. 7). During high discharges, in general, the temperatures are also high. High values of discharge and temperature are observed during hot months. The water temperature of the Gökpınar springs ranges between $10.8-11.1^{\circ} \mathrm{C}$, and variation is only $0.3^{\circ} \mathrm{C}$. Based on Gürün meteorological station data (1973-1995), mean monthly temperature ranges between $-3.5^{\circ} \mathrm{C}$ (January)

karst aquifer in the study area (Yüceyurt limestone) is fed mainly from infiltration of the precipitation. The precipitation falling over the karstified limestone outcrops easily infiltrates through a great number of joints, fractures, solution channels, sinkholes, and ponors. In addition, there is indirect recharge from infiltration of temporary surface waters. The drainage of the Yüceyurt formation is almost entirely underground.

The study area is located in a transition zone between typical semi-arid climate of Central Anatolia and Mediterranean climate. The climate is characterised by dry and warm summers and a cold and wet period that occurs during autumn, winter and spring. Precipitation distribution over the year is irregular. The monthly precipitation reaches a maximum during April and a minimum in August. Precipitation primarily occurs during cold seasons, and its distribution

and $21.4^{\circ} \mathrm{C}$ (July), and the mean annual temperature is $9.2^{\circ} \mathrm{C}$. High water temperatures of the Gökpınar springs, greater than the mean air temperature, are likely to be the consequence of the groundwater circulation system within the karst aquifer.

\section{RECHARGE OF THE KARST AQUIFER}

In karst areas "localized recharge" (Lerner 1997; Hendrickx \& Walker 1997) type of groundwater recharge is generally dominated. During localized recharge, the water percolates rapidly into karst aquifer through cracks, fissures or solution channels (De Vries \& Simmers 2002). In dry season, the recharge of the karst aquifer is much smaller. High-intensity winter precipitation is highly effective in enhancing recharge. During the wet season (between November and May in the Mediterranean region) $70-90 \%$ of the precipitation recharges the karst aquifer (Milanovic 1981). Hoetzl (1995) reported that on an exposed karst area in Saudi Arabia, 45\% of the average rainfall disappears into sinkholes and corrosionally extended joints. Günay \& Yayan (1979) calculated the infiltration percent of the precipitation as $45 \%$ for Kırkgöz karst springs (Antalya, Turkey) using discharges of the springs.

The movement of the water through the karst aquifer depends upon matrix (intergranular), fracture and solution (conduit) permeability. In karst aquifers the water flow through the karst conduits is dominated. The among the months allows a higher infiltration into the karst aquifer. The precipitation occurs mostly as snow during winter (December-March), which can have a significant effect on the recharge of the groundwater in the karst aquifer. According to Fiorillo (2009), in Mediterranean climates, the precipitation that occurs up to MarchApril of each hydrological year recharges karst aquifers, and subsequent precipitation, up to September-October, generally does not recharge the aquifers.

In the flow systems of the carbonate rock province, recharge is commonly derived from precipitation in the mountains. The higher mountains receive larger amounts of precipitation and generate the higher portion of recharge (Hershey et al. 2010). The mean annual precipitation values of the meteorological stations in the vicinity of the study area range between $306 \mathrm{~mm}$ and 740 $\mathrm{mm}$ (Tab. 2). The precipitation generally increases with altitude of the station. Kandil, Sevdili and Adatepe stations are situated to the south of the study area and receive the precipitation mainly under the influence of the moist air front coming from Eastern Mediterranean Sea. The meteorological data of the above mentioned stations are limited and there is no meteorological station at high altitudes (above 1,500 $\mathrm{m}$ a.s.l.) in the vicinity of the study area. Hezanli Mountain (2,283 m a.s.l.) constitutes an important part of the Gökpınar Springs' recharge area which lies between $1,450 \mathrm{~m}$ and $2283 \mathrm{~m}$ a.s.l. The precipitation amounts recorded at meteorological stations 
Tab. 2: Mean annual precipitations of the meteorological stations in the vicinity of the study area.

\begin{tabular}{c|c|c|c|c}
\hline Station name & Operating organization & $\begin{array}{c}\text { Altitude of the station } \\
(\boldsymbol{m})\end{array}$ & $\begin{array}{c}\text { Gauging period } \\
\begin{array}{c}\text { Mean annual precipitation } \\
(\mathbf{m m})\end{array}\end{array}$ \\
\hline Gürün & DMi & 1,250 & $1980-1995$ & 306 \\
\hline Kandil & DSi & 1,280 & $1981-1995$ & 411 \\
\hline Sevdili & DSi & 1,470 & $1981-1995$ & 355 \\
\hline Adatepe & DSi & 1,330 & $1981-1995$ & 740 \\
\hline
\end{tabular}

Tab. 3: Discharges of the Gökpinar springs $\left(\mathrm{m}^{3} / \mathrm{s}\right)$, and discharge coefficients $(\alpha)$ and storage capacities $\left(V_{s}\right)$ calculated from spring discharge hydrograph.

\begin{tabular}{c|c|c|c}
\hline Date of measurement & $\begin{array}{c}\text { Gökpınar-1 spring } \\
\text { (GK-1) }\end{array}$ & $\begin{array}{c}\text { Gökpınar-2 } \\
\text { spring (GK-2) }\end{array}$ & $\begin{array}{c}\text { Total of the } \\
\text { GK-1 and GK-2 }\end{array}$ \\
\hline 02.08 .1995 & 3.015 & 2.650 & 5.665 \\
\hline 29.09 .1995 & 2.595 & 2.280 & 4.875 \\
\hline 31.10 .1995 & 2.295 & 2.175 & 4.470 \\
\hline 22.04 .1996 & 2.415 & 2.865 & 5.280 \\
\hline 30.05 .1996 & 4.025 & 3.200 & 7.225 \\
\hline 16.07 .1996 & 4.425 & 3.395 & 7.820 \\
\hline 13.08 .1996 & 4.225 & 2.925 & 7.150 \\
\hline 27.09 .1996 & 3.630 & 2.730 & 6.360 \\
\hline Average discharge & 3.320 & 2.780 & 6.100 \\
\hline Discharge coefficient, $\alpha\left(\right.$ dayy $\left.^{-1}\right)$ & $2.71 \times 10^{-3}$ & $2.98 \times 10^{-3}$ & \\
\hline Storage capacity, $\mathrm{V}_{\mathrm{s}}\left(\mathrm{m}^{3}\right)$ & $141 \times 10^{6}$ & $98 \times 10^{6}$ & \\
\hline
\end{tabular}

\section{DISCHARGE OF THE SPRINGS}

The discharges of the Gökpınar springs, Gökpınar stream and Tohma river measured during the field work of this study are given in Tab. 3 and Tab. 4. In springs the minimum discharges were measured in September 1996 and October 1995, and the maximum in July 1996. The minimum discharge in Gökpinar stream is in October, and maximum discharge (Tab. 2) may easily increase by a factor of two or more at higher elevations of the recharge area. Because of the scarcity of the meteorological data, calculation of a complete water budget could not be performed.

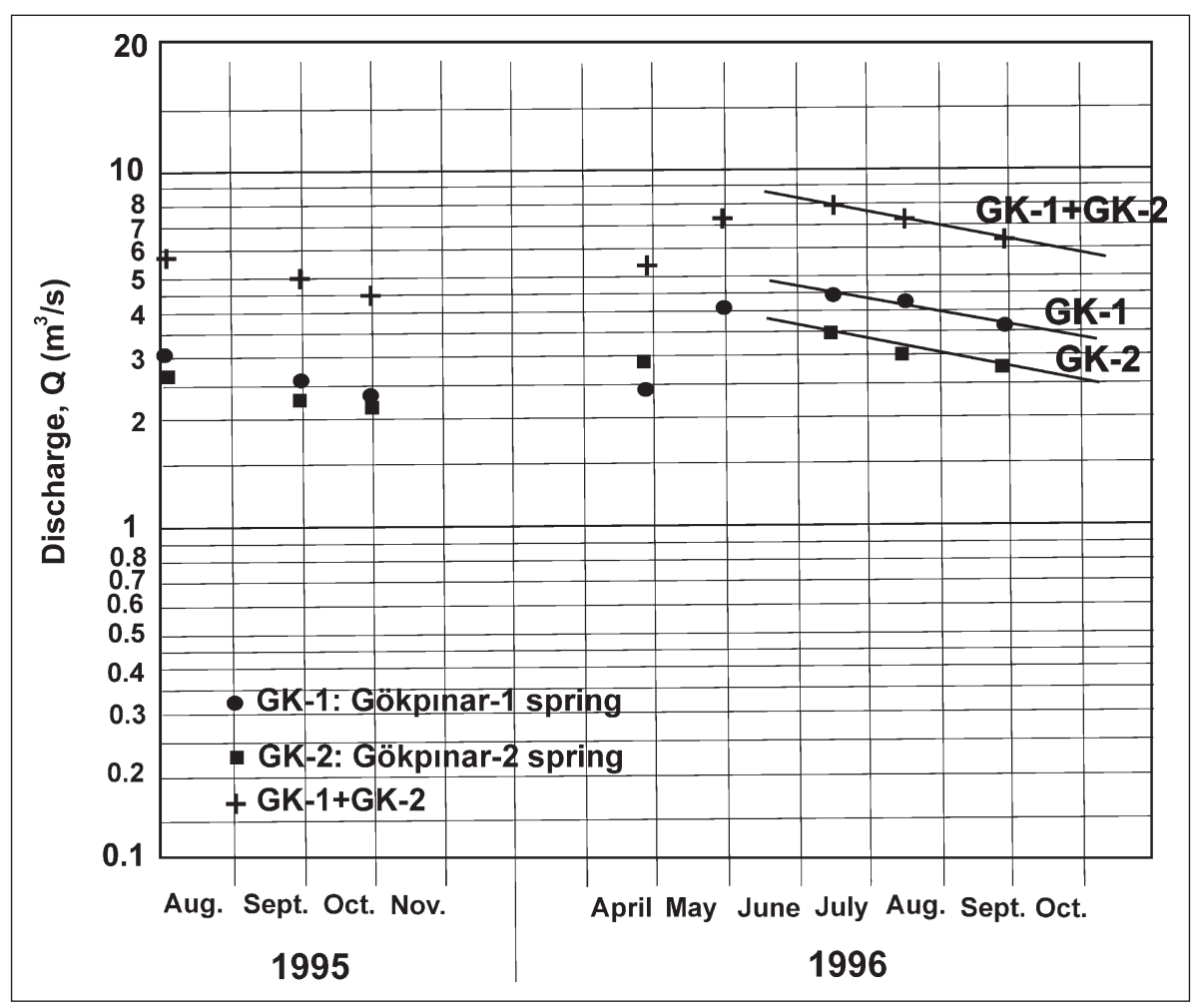

Fig. 8: Discharge graph of the Gökpınar springs (modified from Kaçaroğlu 2006). is in July. Gökpınar stream is mainly fed by the water discharged via Gökpınar springs. The upstream segment of the Gökpınar stream is an intermittent stream which is dry during a long period of the year. Gökpınar stream makes a great contribution to the discharges of the Tohma river (Tab. 4).

Analysis of the spring recession hydrograph offers considerable potential insight into the nature and operation of the karst drainage system and provide information on the volume of water held in storage (Bonacci 1993). It also allows calculating the amount of the water drained through a particular spring from the beginning of the recession. These characteristics are important for evaluating water resources, especially in water deficient regions (Amit et al. 2002).

The period after the spring rains, in some precipitation regimes, when the water input into the aquifer is practically zero (recession period) is the most suitable 
Tab. 4: Discharges of Gökpinar stream and Tohma river $\left(\mathrm{m}^{3} / \mathrm{s}\right)$.

\begin{tabular}{l|l|c|c|c|c|c|c|c|c}
\hline \multirow{2}{*}{$\begin{array}{l}\text { Stream/river/ } \\
\text { measurement } \\
\text { point }\end{array}$} & Location of the measurement point & \multicolumn{7}{|c}{ Date of measurement } \\
\cline { 3 - 9 } $\begin{array}{l}\text { Gökpınar stream } \\
\text { GD-1 }\end{array}$ & Downstream of the Gökpınar springs & 5.665 & 4.875 & 4.475 & 5.410 & 7.275 & 7.820 & 7.155 & 6.060 \\
\hline $\begin{array}{l}\text { Gökpınar stream } \\
\text { GD-2 }\end{array}$ & $\begin{array}{l}\text { Suçatı-Upstream of the Tohma river } \\
\text { connection }\end{array}$ & 6.250 & 5.100 & 5.250 & 5.850 & 7.850 & 8.350 & 8.085 & 6.665 \\
\hline $\begin{array}{l}\text { Tohma river } \\
\text { TÇ-1 }\end{array}$ & $\begin{array}{l}\text { Suçatı-Upstream of the Gökpınar } \\
\text { stream connection }\end{array}$ & 0.950 & 1.510 & 1.815 & 6.905 & 3.180 & 2.570 & 1.925 & 2.245 \\
\hline $\begin{array}{l}\text { Tohma river } \\
\text { TÇ-2 }\end{array}$ & $\begin{array}{l}\text { Suçatı-Downstream of the Gökpınar } \\
\text { stream connection }\end{array}$ & 7.100 & 6.650 & 7.050 & 13.00 & 11.25 & 10.92 & 10.10 & 8.910 \\
\hline
\end{tabular}

for this analysis (Milanovic 1981; Ford \& Williams 2007; Bonacci 2001; White 2002). Maillet (1905) provided the first mathematical characterization of the baseflow recession. This interpretation is based on the drainage of a simple reservoir (Kovacs et al. 2005).

In dry period, during which there is no water input into the aquifer, the dynamic water reserve in the aquifer from which the spring outflows decreases as a function of time, and the groundwater level declines. Maillet (1905) proposed that the discharge of a spring is a function of the water volume held in storage and described it by the simple exponential relation (Milanovic 1981; Ford \& Williams 2007):

$$
Q_{t}=Q_{0} \cdot e^{-\alpha t} \text { or } Q_{t}=Q_{0} \cdot e^{-\alpha(t-t o)}
$$

where $Q_{t}$ is the discharge $\left(\mathrm{m}^{3} / \mathrm{s}\right)$ at time $t ; \mathrm{Q}_{\mathrm{O}}$ is previous discharge at time zero $\left(\mathrm{t}_{\mathrm{O}}\right) ; \mathrm{t}\left(\right.$ or $\left.\mathrm{t}-\mathrm{t}_{\mathrm{O}}\right)$ is the time elapsed (usually expressed in days) between $Q_{t}$ and $Q_{O}$; $\mathrm{e}$ is the base of the natural logarithm; and $\alpha$ is termed recession (discharge) coefficient $\left[\mathrm{T}^{-1}\right]$.

Maillet's (1905) equation recession analysis of the discharges of the Gökpınar springs (Tab. 3 \& Fig. 8) were performed, and recession coefficients $(\alpha)$ and dynamic volume (storage capacity, $\mathrm{V}_{\mathrm{s}}$ ) of the aquifer were calculated. The recession (discharge) coefficients of the Gökpınar-1 (GK-1) and Gökpınar-2 (GK-2) springs are $\alpha_{\mathrm{GK}-1}=2.71 \times 10^{-3} \mathrm{day}^{-1}$ and $\alpha_{\mathrm{GK}-2}=2.98 \times 10^{-3} \mathrm{day}^{-1}$, and dynamic volume (storage capacity) values are $\mathrm{V}_{\mathrm{s}(\mathrm{GK}-1)}=$ $141 \times 10^{6} \mathrm{~m}^{3}$ and $\mathrm{V}_{\mathrm{s}(\mathrm{GK}-2)}=98 \times 10^{6} \mathrm{~m}^{3}$.

The value of the recession coefficient derives from the hydrogeological characteristics of the aquifer, espe- cially effective porosity and transmissivity. It represents the capability of the aquifer to release water. Small values of $\alpha$ indicate very slow drainage of the karst aquifer with a large storage capacity. The springs of this type of aquifer are mostly permanent. Large values of $\alpha$ (the recession curve is steep) indicate rapid drainage of conduits and little underground storage (Milanovic 1981; Ford \& Williams 2007).

The values of the recession coefficients calculated for Gökpınar springs and little changes in the discharge through the year indicate that the Yüceyurt limestone karst aquifer has a large storage capacity and the drainage occurs very slowly. The discharge of the springs are not being directly affected by the monthly variations of the precipitation.

Recession coefficients were calculated using Maillet (1905) approach for some large karst springs in Taurid Karst Belt (Turkey) by various researchers. Çelik \& Afşin (1996) obtained a mean value of $6.92 \times 10^{-3}$ day $^{-1}$ for Kazanpınarı karst spring in Elmalı Polje, Antalya. Günay \& Yayan (1979) calculated recession coefficients rangin from $3.1 \times 10^{-3}$ day $^{-1}$ to $6.2 \times 10^{-3}$ day $^{-1}$ for Kurgöz karst springs, north of Antalya. Yevjevich (1985) obtained a recession coefficient of $2.6 \times 10^{-3}$ day $^{-1}$ for Dumanl spring, Manavgat river basin-Antalya. Similar recession coefficient values of the Gökpınar springs and the above mentioned springs may be interpreted as karst aquifer of the Gökpınar springs (Yüceyurt limestone) has similar hydrogeological characteristics that of the karst aquifers in the Antalya region. As mentioned before the study area is located in the eastern part of the Taurid Karst Belt.

\section{HYDROCHEMISTRY}

\section{CHEMICAL CHARACTER OF THE WATERS}

Carbonate reactions are very important in controlling the composition of groundwater. Rocks made of car- bonates, such as limestones and dolomites, are often aquifers that have a high productivity. The main minerals in these rocks are $\mathrm{Ca}$ - and $\mathrm{Mg}$ - carbonates which react 
Tab. 5: Water analyses data of the Gökpinar springs.

\begin{tabular}{|c|c|c|c|c|c|c|c|c|c|c|c|c|c|c|c|}
\hline \multirow{2}{*}{$\begin{array}{c}\text { Samp. } \\
\text { no. }\end{array}$} & \multirow{2}{*}{$\begin{array}{c}\text { Date of } \\
\text { sampling }\end{array}$} & \multirow[t]{2}{*}{$T\left({ }^{\circ} \mathrm{C}\right)$} & \multirow[t]{2}{*}{ pH } & \multirow{2}{*}{$\begin{array}{c}E C \\
(\mu S / \mathrm{cm})\end{array}$} & \multirow{2}{*}{$\begin{array}{c}\text { TDS } \\
(\mathrm{mg} / \mathrm{L})\end{array}$} & \multicolumn{4}{|c|}{ Cations (mg/L) } & \multicolumn{4}{|c|}{ Anions (mg/L) } & \multirow{2}{*}{$\begin{array}{c}\text { Hardness } \\
\left(\mathrm{mg}^{\prime} / \mathrm{CaCO}_{3}\right)\end{array}$} & \multirow[t]{2}{*}{$\mathrm{Ca} / \mathrm{Mg}$} \\
\hline & & & & & & $\mathrm{Na}$ & K & $\mathrm{Ca}$ & $M g$ & $\mathrm{CO}_{3}$ & $\mathrm{HCO}_{3}$ & $\mathrm{Cl}$ & $\mathrm{SO}_{4}$ & & \\
\hline \multicolumn{16}{|c|}{ Sampling point: Gökpınar-1 spring (GK-1) } \\
\hline 1 & 02.08.1995 & 10.8 & 7.65 & 280 & 180 & 2.4 & 1.0 & 40.0 & 9.0 & 0.0 & 150.0 & 5.5 & 11.0 & 137 & 2.695 \\
\hline 22 & 29.09 .1995 & 11.0 & 7.90 & 295 & 190 & 2.3 & 0.9 & 46.0 & 8.5 & 0.0 & 153.0 & 7.5 & 12.5 & 150 & 3.281 \\
\hline 32 & 31.10 .1995 & 10.8 & 7.92 & 305 & 180 & 2.1 & 1.0 & 48.0 & 8.0 & 0.0 & 153.0 & 9.0 & 11.5 & 155 & 3.638 \\
\hline 43 & 24.04 .1996 & 11.0 & 7.80 & 310 & 200 & 2.6 & 1.2 & 50.0 & 6.0 & 0.0 & 150.0 & 5.5 & 16.5 & 150 & 5.053 \\
\hline 52 & 30.05 .1996 & 11.0 & 7.85 & 298 & 190 & 2.4 & 1.1 & 54.0 & 5.0 & 0.0 & 158.0 & 3.5 & 16.0 & 156 & 6.548 \\
\hline 62 & 17.07.1996 & 11.1 & 7.75 & 270 & 180 & 2.2 & 1.0 & 48.0 & 4.5 & 0.0 & 147.0 & 5.0 & 12.0 & 139 & 6.467 \\
\hline 72 & 13.08 .1996 & 11.0 & 7.85 & 285 & 180 & 2.0 & 0.9 & 46.0 & 5.0 & 0.0 & 150.0 & 4.5 & 11.5 & 136 & 5.578 \\
\hline 82 & 27.09 .1996 & 11.0 & 7.85 & 280 & 180 & 2.1 & 1.0 & 48.0 & 6.0 & 0.0 & 145.0 & 5.0 & 13.5 & 145 & 4.851 \\
\hline \multicolumn{2}{|l|}{ Minimum } & 10.8 & 7.65 & 270 & 180 & 2.0 & 0.9 & 40.0 & 4.5 & 0.0 & 145.0 & 3.5 & 11.0 & 136 & 2.695 \\
\hline \multicolumn{2}{|l|}{ Maximum } & 11.1 & 7.92 & 310 & 200 & 2.6 & 1.2 & 54.0 & 9.0 & 0.0 & 158.0 & 9.0 & 16.5 & 156 & 6.548 \\
\hline \multicolumn{2}{|l|}{ Mean } & 11.0 & 7.82 & 290 & 185 & 2.3 & 1.0 & 47.5 & 6.5 & 0.0 & 151.0 & 5.7 & 13.1 & 146 & 4.431 \\
\hline \multicolumn{16}{|c|}{ Sampling point: Gökpınar-2 spring (GK-2) } \\
\hline 2 & 02.08 .1995 & 10.9 & 7.80 & 285 & 190 & 2.5 & 1.1 & 40.0 & 10.0 & 0.0 & 144.0 & 5.5 & 11.5 & 141 & 2.425 \\
\hline 21 & 29.09 .1995 & 10.9 & 7.95 & 307 & 200 & 2.3 & 1.0 & 44.0 & 10.0 & 0.0 & 153.0 & 7.5 & 12.0 & 151 & 2.668 \\
\hline 31 & 31.10 .1995 & 10.8 & 7.90 & 306 & 200 & 2.2 & 0.9 & 48.0 & 8.5 & 0.0 & 150.0 & 7.0 & 12.0 & 155 & 3.424 \\
\hline 42 & 24.04 .1996 & 10.9 & 7.65 & 310 & 200 & 2.5 & 1.3 & 50.0 & 6.0 & 0.0 & 150.0 & 5.5 & 16.5 & 150 & 5.053 \\
\hline 51 & 30.05 .1996 & 11.0 & 7.85 & 298 & 190 & 2.8 & 1.2 & 54.0 & 5.0 & 0.0 & 158.0 & 3.5 & 13.0 & 156 & 6.548 \\
\hline 61 & 17.07.1996 & 11.1 & 7.90 & 285 & 190 & 2.4 & 1.1 & 50.0 & 6.0 & 0.0 & 153.0 & 3.5 & 12.0 & 150 & 5.053 \\
\hline 71 & 13.08 .1996 & 10.9 & 7.95 & 270 & 170 & 2.1 & 1.0 & 44.0 & 6.5 & 0.0 & 150.0 & 4.5 & 9.0 & 137 & 4.104 \\
\hline 81 & 27.09.1996 & 10.9 & 7.95 & 285 & 180 & 2.3 & 1.1 & 50.0 & 5.0 & 0.0 & 147.0 & 5.0 & 14.0 & 146 & 6.063 \\
\hline \multicolumn{2}{|l|}{ Minimum } & 10.8 & 7.65 & 270 & 170 & 2.1 & 0.9 & 40.0 & 5.0 & 0.0 & 144.0 & 3.5 & 9.0 & 137 & 2.425 \\
\hline \multicolumn{2}{|l|}{ Maximum } & 11.1 & 7.95 & 310 & 200 & 2.8 & 1.3 & 54.0 & 10.0 & 0.0 & 158.0 & 7.5 & 16.5 & 156 & 6.548 \\
\hline \multicolumn{2}{|l|}{ Mean } & 10.9 & 7.87 & 293 & 190 & 2.4 & 1.1 & 47.5 & 7.1 & 0.0 & 151.0 & 5.3 & 12.5 & 148 & 4.056 \\
\hline
\end{tabular}

easily with groundwater and give water its "hard" character (Appello \& Postma 1996). The physico-chemical characteristics of groundwaters in karstic systems are determined by the lithology of the rocks that they cross, the physico-chemical processes that predominate, the residence time of water and the various conditions and modes of circulation that coexist within them (LopezChicano et al. 2001).

In order to identify the chemical character of the waters of the karst springs, field measurements and laboratory analyses were carried out on the water samples collected between August 1995-September 1996 (Tabs. 5 \& 6).

The waters of the Gökpınar springs and the other low yield springs are not rich (Tabs. $5 \& 6$ ) in major ions and total dissolved solids. Total dissolved solids (TDS) are moderate according to the classification proposed by Smith et al. (1993). The order of predominance of ions of the spring waters is $\mathrm{Ca}^{2+}>\mathrm{Mg}^{2+}>\mathrm{Na}^{+}$for cations and $\mathrm{HCO}_{3}^{-}>\mathrm{SO}_{4}^{2+}>\mathrm{Cl}^{-}$for the anions. $\mathrm{Ca}^{2+}$ and $\mathrm{HCO}_{3}^{-}$are dominant dissolved species in the waters of the Gökpınar springs and low yield springs due to the mineralogical composition of the karst aquifer. This also indicate the dissolution and precipitation of the predominant carbonate rocks in the aquifer.
The mean values of the water quality parameters in Gökpinar-1 (GK-1) spring waters are as follows (Tab. 5): $\mathrm{T}=11.0^{\circ} \mathrm{C}, \mathrm{pH}=7.82$, $\mathrm{EC}=290 \mathrm{mS} / \mathrm{cm}, \quad \mathrm{TDS}=185 \mathrm{mg} / \mathrm{L}, \quad \mathrm{Na}^{+}=2.3 \mathrm{mg} / \mathrm{L}$, $\mathrm{K}^{+}=1.0 \mathrm{mg} / \mathrm{L}, \quad \mathrm{Ca}^{2+}=47.5 \mathrm{mg} / \mathrm{L}, \quad \mathrm{Mg}^{2+}=6.5 \mathrm{mg} / \mathrm{L}$, $\mathrm{HCO}_{3}^{-}=151.0 \mathrm{mg} / \mathrm{L}, \mathrm{Cl}^{-}=5.7 \mathrm{mg} / \mathrm{L}, \quad \mathrm{SO}_{4}^{2+}=13.1 \mathrm{mg} / \mathrm{L}$, Hardness $=146 \mathrm{mg} / \mathrm{L} \mathrm{CaCO}_{3}$. The mean values of the same parameters for Gökpinar-2 (GK-2) spring waters are $10.9^{\circ} \mathrm{C}, 7.87,293 \mathrm{mS} / \mathrm{cm}, 190 \mathrm{mg} / \mathrm{L}, 2.4 \mathrm{mg} / \mathrm{L}$, $1.1 \mathrm{mg} / \mathrm{L}, 47.5 \mathrm{mg} / \mathrm{L}, 7.1 \mathrm{mg} / \mathrm{L}, 151.0 \mathrm{mg} / \mathrm{L}, 5.3 \mathrm{mg} / \mathrm{L}$, $12.5 \mathrm{mg} / \mathrm{L}, 148 \mathrm{mg} / \mathrm{L} \mathrm{CaCO}_{3}$, respectively. In both springs these parameters and the amounts of the dissolved ions do not change significantly between wet and dry seasons. EC, TDS, and cation and anion concentrations of the Gökpınar springs have lower values which may be attributed to the short residence time of the water in the karst aquifer.

The ranges of the water quality parameters of the low yield springs are as follows (Tab. 6): $\mathrm{EC}=270-435 \mathrm{~S} / \mathrm{cm}, \mathrm{TDS}=180-230 \mathrm{mg} / \mathrm{L}, \mathrm{Na}^{+}=1.4-4.2 \mathrm{mg} / \mathrm{L}$, $\mathrm{K}^{+}=0.5-3.4 \mathrm{mg} / \mathrm{L}, \mathrm{Ca}^{2+}=38-60 \mathrm{mg} / \mathrm{L}, \mathrm{Mg}^{2+}=4.5-10 \mathrm{mg} / \mathrm{L}$, $\mathrm{HCO}_{3}^{-}=134-198 \mathrm{mg} / \mathrm{L}, \mathrm{Cl}^{-}=3.5-10.5 \mathrm{mg} / \mathrm{L}, \mathrm{SO}_{4}^{2+}=3.0-$ $19.5 \mathrm{mg} / \mathrm{L}$, Hardness $=125-181 \mathrm{mg} / \mathrm{L} \mathrm{CaCO}_{3}$.

In a study of the carbonate springs in the central Appalachians, Shuster \& White (1971) observed that 


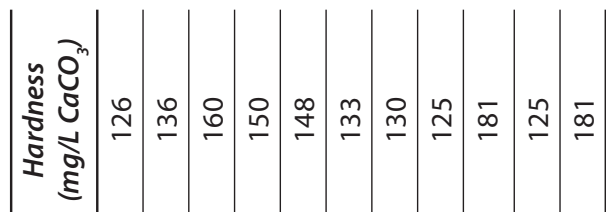

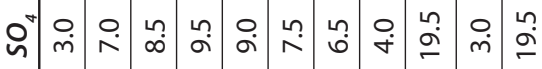

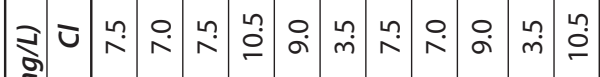
紊究

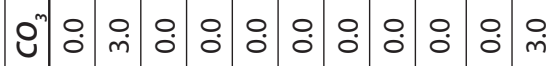

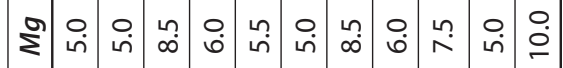

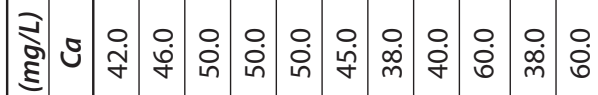
气ิ

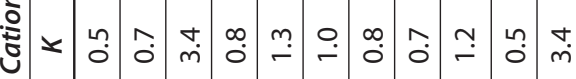

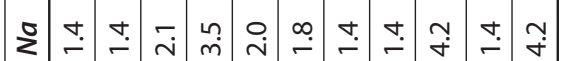
in बे

胥

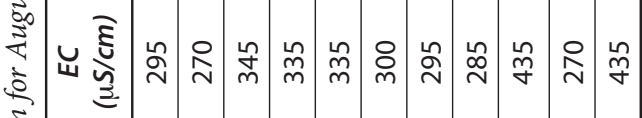
s

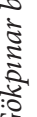
: 辛 $\Xi$

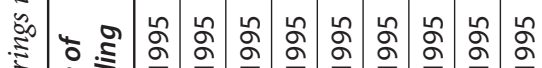
के $\stackrel{3}{2}$ हे $\frac{2}{\text { क }}$

b

章

ते

离 $\frac{\pi^{2}}{3}$ $\ddot{6}$ हैं

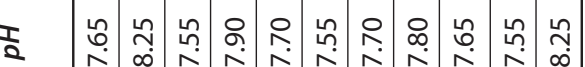

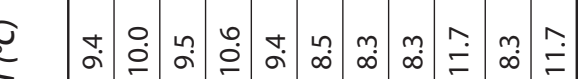

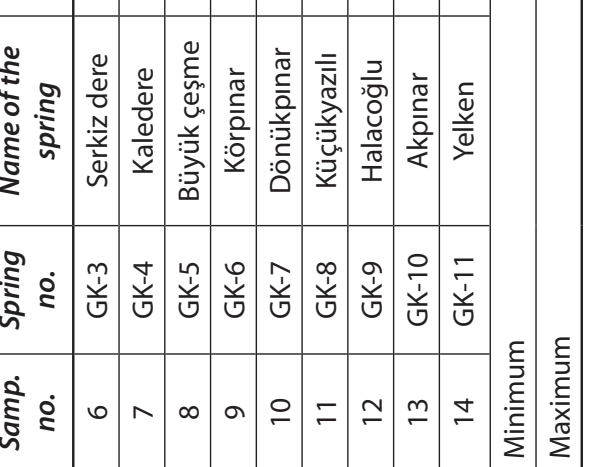

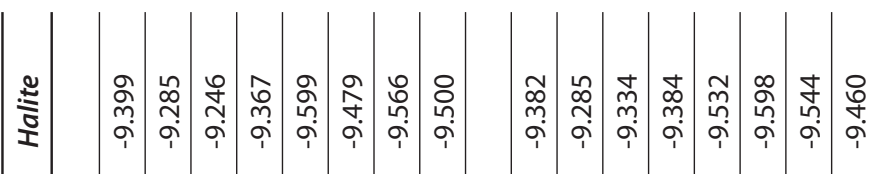

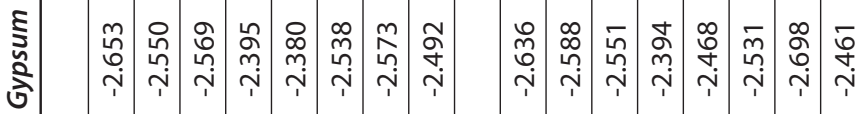

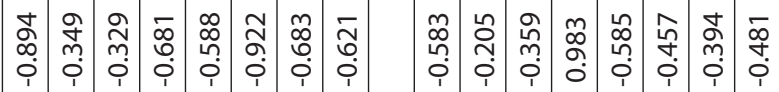

๖ำ

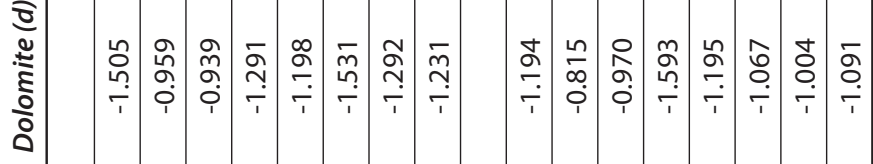

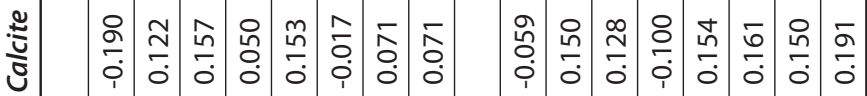

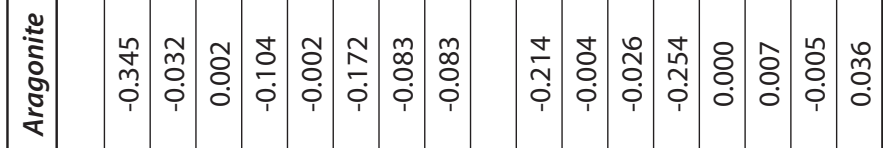

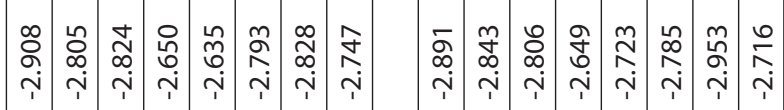

$=$ ผ 苟

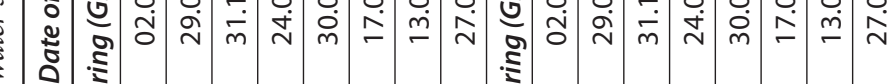
ลे

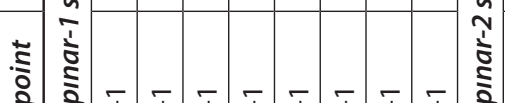

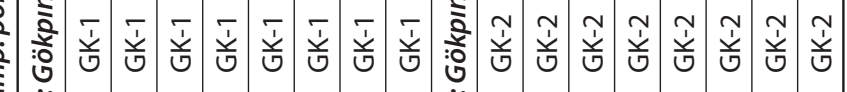

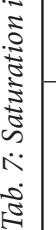

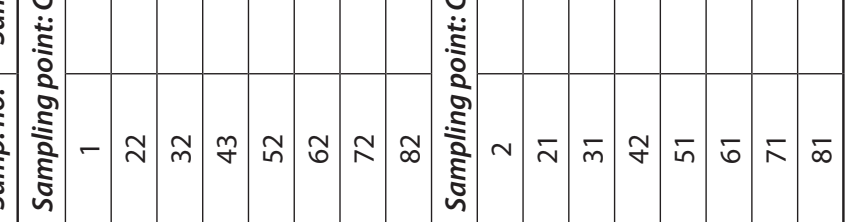


conduit springs were very variable in hardness throughout of the year (coefficient of variation 10-24\%). Diffuse springs had a rather constant hardness (coefficient of variation $<5 \%$ ). The hardness of the Gökpınar streams do not show considerable changes in time. The coefficient of the variation of the hardness for GK-1 and GK-2 are $5.5 \%$ and $4.5 \%$, respectively. Regarding the classification of the Shuster and White (1971) Gökpınar springs do not exhibit complete diffuse and conduit type character.

Jacobson \& Langmuir (1974) investigated the discharge and geochemistry of the carbonate springs in fact that the springs issue from Yüceyurt formation which mainly consists of limestone and partially dolomitic limestone. The $\mathrm{Ca}^{2+} / \mathrm{Mg}^{2+}$ ratio provides information on the rock type through which the groundwater has passed. The $\mathrm{Ca}^{2+} / \mathrm{Mg}^{2+}$ ratio ranges from 1 to 1.5 for dolomite aquifers, and from 6 to 8 for limestone aquifers. Intermediate values indicate a dolomitic limestone or a mixed limestonedolomite sequence (White 1999).

$\mathrm{HCO}_{3}^{-}$is the dominant dissolved anion in the waters of the study area. $\mathrm{HCO}_{3}^{-}$concentrations of the Gökpinar springs varies between 144 and $158 \mathrm{mg} / \mathrm{L}$. In low yield springs $\mathrm{HCO}_{3}^{-}$contents range from 134 to 198 $\mathrm{mg} / \mathrm{L}$. On an equivalent basis (meq/L), $\mathrm{HCO}_{3}$ accounts for $85 \%$ to $86 \%$ of the anions in Gökpinar springs and $83 \%$ to $86 \%$ of the anions in low yield springs. The high concentrations of $\mathrm{HCO}_{3}^{-}$in the water indicate intensive chemical weathering mainly carbonate dissolution occurring in the recharge area of the springs which is consistent with the lithological composition of the karst aquifer.

The water analyses are presented in a Piper diagram (Piper 1944) (Fig. 9). The diagram represents the concentrations as percentages. Using this diagram the water analyses can be classified into types or hydro-

central Pennsylvania. The researchers distinguished three types of karst springs as conduit, diffuse-conduit, and diffuse. The water chemistry data of the Gökpınar springs suggest that they are conduit type regarding to the EC values (EC 270-310 S/cm), and are diffuse type regarding to the coefficients of variation of the EC (4.8\%) and discharge (26\% for GK-1 and $15 \%$ for GK-2). The discharges of the Gökpınar springs show larger variation than the other chemical variables. Jacobson \& Langmuir (1974) explains such a situation by buffering effect on the water quality relative to discharge.

$\mathrm{Ca}^{2+}, \mathrm{HCO}_{3}^{-}$and hardness concentrations of the Gökpınar springs do not change markedly with time while $\mathrm{Mg}^{2+}$ concentrations exhibit significant change in time. On an equivalent basis (meq/L) $\mathrm{Ca}^{2+} / \mathrm{Mg}^{2+}$ ratios of the Gökpınar springs range from 2.7 to 6.6 for GK-1, and from 2.4 to 6.6 for GK-2 (Tab. 5). These ratios indicate mainly limestone dissolution and consistent with the chemical facieses (Back 1966). The diagram displays the relations between rock type and water composition, and evolution of the composition along its route (Appelo \& Postma 1996; Drever 1997). The water samples plotted near the left corners of the cation and anion triangles, and are rich in $\mathrm{Ca}^{2+}$ and $\mathrm{HCO}_{3}^{-}$. Therefore, with regard to the Piper diagram (Fig. 9), all waters are "calcium bicarbonate" type.

Regarding the limits in Turkish Drinking Water Standards (TSE 2005) all spring waters in the study area are suitable for drinking. The recharge area of the Gökpınar springs is sparsely populated and there is no industrial, mining and agricultural activity that may cause water pollution.

\section{SATURATION STATE}

The saturation indices (SI) describe quantitatively the deviation of water from equilibrium with respect to dis- 


\begin{tabular}{|c|c|c|c|c|c|c|c|c|c|c|}
\hline & & & 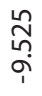 & 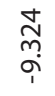 & $\begin{array}{l}\hat{n} \\
\text { م. } \\
\text { ô }\end{array}$ & $\begin{array}{l}\stackrel{n}{0} \\
\stackrel{i}{i}\end{array}$ & 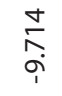 & $\begin{array}{l}\bar{\sigma} \\
\sigma \\
\sigma\end{array}$ & $\begin{array}{l}\frac{a}{n} \\
\bar{i}\end{array}$ & 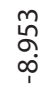 \\
\hline & & & 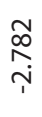 & 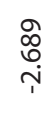 & $\begin{array}{l}\hat{\tilde{O}} \\
\stackrel{\leftrightarrow}{i} \\
\text { }\end{array}$ & $\begin{array}{l}\bar{n} \\
\stackrel{i}{i} \\
\text { in }\end{array}$ & $\underset{\substack{n \\
i}}{\stackrel{n}{i}}$ & $\begin{array}{l}\text { O } \\
\infty \\
i \\
i\end{array}$ & $\begin{array}{l}\stackrel{P}{0} \\
\text { r. }\end{array}$ & $\begin{array}{l}\stackrel{D}{0} \\
\stackrel{\sim}{\Upsilon}\end{array}$ \\
\hline & & & $\begin{array}{l}\hat{m} \\
\text { o. } \\
\text { of }\end{array}$ & $\begin{array}{l}0 \\
\bar{\sigma} \\
\text { in }\end{array}$ & \begin{tabular}{l}
\multirow{0}{0}{} \\
m. \\
i
\end{tabular} & $\begin{array}{l}\text { no } \\
\infty \\
i \\
i\end{array}$ & $\begin{array}{l}\stackrel{0}{n} \\
\stackrel{m}{T} \\
T\end{array}$ & $\begin{array}{l}\text { no } \\
\infty \\
i \\
i\end{array}$ & $\begin{array}{l}\text { D } \\
\infty \\
o \\
i\end{array}$ & $\frac{\pi}{\stackrel{i}{i}}$ \\
\hline & & & $\begin{array}{l}\sqrt{n} \\
0 \\
0\end{array}$ & 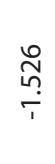 & $\begin{array}{l}\text { ñ } \\
\text { ò } \\
\text { in }\end{array}$ & $\underset{\frac{N}{n ! n}}{n}$ & $\frac{\hat{a}}{\grave{T}}$ & $\stackrel{\bar{n}}{\frac{n}{n}}$ & 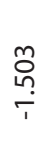 & $\underset{\substack{\hat{i} \\
\text { i }}}{ }$ \\
\hline & & & $\begin{array}{l}\text { Oे } \\
\text { +े } \\
\text { d. }\end{array}$ & $\stackrel{n}{\stackrel{n}{\circ}}$ & 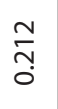 & $\begin{array}{l}\tilde{O} \\
\stackrel{0}{i} \\
\dot{i}\end{array}$ & $\begin{array}{l}\stackrel{f}{\sim} \\
\stackrel{i}{i}\end{array}$ & \begin{tabular}{l}
8 \\
\hdashline \\
\\
1
\end{tabular} & $\begin{array}{l}\text { No } \\
\hat{O} \\
\text { i. }\end{array}$ & $\begin{array}{l}\text { ণ্ } \\
\text { }\end{array}$ \\
\hline & & & 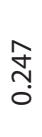 & $\begin{array}{l}\bar{\infty} \\
\stackrel{0}{N} \\
1\end{array}$ & 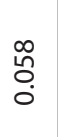 & $\frac{\infty}{\stackrel{\infty}{0}}$ & $\begin{array}{l}m \\
\stackrel{o}{+} \\
0 \\
i\end{array}$ & $\begin{array}{l}\stackrel{n}{N} \\
\stackrel{p}{i} \\
i\end{array}$ & 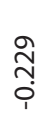 & 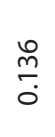 \\
\hline & & & $\begin{array}{l}\hat{\tilde{o}} \\
\dot{p}\end{array}$ & 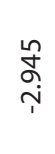 & 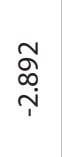 & 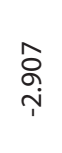 & $\stackrel{m}{\frac{m}{m}}$ & $\frac{\hat{f}}{\dot{p}}$ & 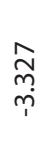 & $\begin{array}{l}\stackrel{N}{N} \\
\stackrel{N}{i}\end{array}$ \\
\hline & & & $\begin{array}{l}n \\
\alpha \\
\sigma \\
\circ \\
\infty \\
\circ \\
\dot{0}\end{array}$ & $\begin{array}{l}\text { nू } \\
\sigma \\
\infty \\
\delta \\
\dot{0}\end{array}$ & $\begin{array}{l}\text { nू } \\
\sigma \\
\circ \\
\infty \\
0 \\
0 \\
0\end{array}$ & $\begin{array}{l}\text { Ln } \\
\alpha \\
\circ \\
o \\
0 \\
0\end{array}$ & $\begin{array}{l}\text { ñ } \\
\alpha \\
\infty \\
\infty \\
0 \\
\dot{0}\end{array}$ & $\begin{array}{l}\text { n } \\
\alpha \\
\circ \\
o \\
\dot{0} \\
\dot{0}\end{array}$ & $\begin{array}{l}n \\
\alpha \\
\circ \\
\infty \\
\circ \\
\dot{0}\end{array}$ & $\begin{array}{l}\text { Lू } \\
\stackrel{2}{0} \\
\infty \\
\circ \\
\dot{0}\end{array}$ \\
\hline & & 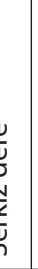 & 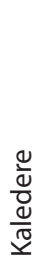 & 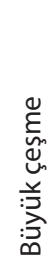 & $\begin{array}{l}\overline{\bar{o}} \\
\stackrel{\overline{0}}{\overline{0}} \\
\frac{\overline{0}}{2}\end{array}$ & 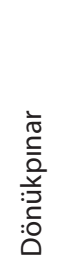 & 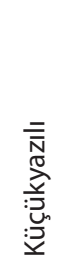 & 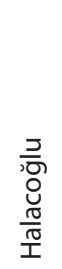 & 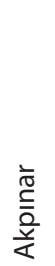 & 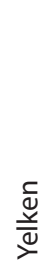 \\
\hline & & & $\begin{array}{l}\text { 竎 } \\
\text { I }\end{array}$ & $\begin{array}{l}\stackrel{n}{\tilde{v}} \\
\stackrel{v}{0}\end{array}$ & $\begin{array}{l}\text { 音 } \\
\text { U }\end{array}$ & 竎 & $\begin{array}{l}\infty \\
\text { I } \\
\text { บ }\end{array}$ & $\begin{array}{l}\text { Iे } \\
\text { Iv }\end{array}$ & $\begin{array}{l}\frac{0}{\dot{v}} \\
\frac{1}{0}\end{array}$ & 咅 \\
\hline & & & 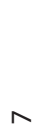 & $\infty$ & $a$ & $\stackrel{\circ}{\circ}$ & $=$ & $\simeq$ & $\stackrel{m}{\sim}$ & 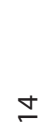 \\
\hline
\end{tabular}

solved minerals. If the water is exactly saturated with the dissolving mineral, saturation index equals to zero $(\mathrm{SI}=0)$. Positive values of SI indicate saturation, and negative ones indicate undersaturation. Saturation state indicates the direction of the processes; for undersaturation dissolution is expected, and supersaturation suggests precipitation.

Saturation indices for anhydrite, aragonite, calcite, dolomite, gypsum and halite minerals were calculated (Tabs. 7 \& 8) using WATEQF computer program (Plummer et al. 1984). The values of the saturation indices for dolomite are given as dolomite (c) and dolomite (d) in Tabs. 7 \& 8. "The (c) and (d) refer well-crystallized (ordered) and disordered dolomite respectively. Wellordered crystals are always less soluble than disordered crystals. The WATEQ4F database includes separate solubilities for crystalline and disordered forms for some solids" (Drever 1977).

All spring waters in the study area are undersaturated with respect to anhydrite, gypsum and halite minerals (Tabs. 7 \& 8). Gökpınar springs (GK-1 and GK-2) are generally undersaturated or slightly saturated with respect to aragonite, slightly saturated for calcite, and undersaturated for dolomite. In August 1995 period, low yield springs in the study area are undersaturated with respect to dolomite, and undersaturated or slightly saturated for aragonite and calcite minerals. Saturation with respect to calcite and undersaturation to dolomite of the Gökpınar springs is in consistence with the mineralogical composition of the karst aquifer lithology. White (1977) states that most chemical reactions occur near the recharge zone of the karst aquifer, and solution rates are highest in the initial stages of the flow paths and decreases considerably within short distances of the recharge zone.

Saturation index (SI) values for calcite calculated for Gökpınar springs are in the range -0.190 to +0.191 . In the study area no calcite (carbonate tuffa) precipitation was observed around the outlets of the springs. Appello \& Postma (1996) interpreted small SI values for calcite as "dissolution of carbonates generally fast enough to reach thermodynamic equilibrium, while precipitation of calcite in natural settings is sluggish when SI values are smaller than 0.3 ". 


\section{CONCLUSIONS}

Gökpinar karst springs are potentially important water resources for water requirements in Gürün district centre, Sivas. At present the water of the springs is used for fish production, power (electricity) generation and irrigation. This study, as the first hydrogeological research in the area, aimed at determination of the hydrogeological and hydrogeochemical characteristics of the Gökpınar karst springs and karstic features of the study area.

The main aquifer in the study area is Jurassic-Cretaceous Yüceyurt formation which is made up of mainly limestone and partially dolomitic limestone. The aquifer exhibits a well developed karst system. Small scale solution sculpture and large scale karst landforms and features are developed in this formation. The groundwater in the karst aquifer (Yüceyurt formation) is discharged by Gökpınar springs which have two main outlets and a total discharge ranging between $4.5 \mathrm{~m}^{3} / \mathrm{s}$ and $7.8 \mathrm{~m}^{3} / \mathrm{s}$.

The recession analysis of the discharges of the Gökpınar-1 and Gökpınar-2 springs has given the storage capacities as $141 \times 10^{6} \mathrm{~m}^{3}$ and $98 \times 10^{6} \mathrm{~m}^{3}$, and the recession (discharge) coefficients as $2.71 \times 10^{-3}$ day $^{-1}$ and $2.98 \times 10^{-3}$ day $^{-1}$, respectively. These values indicate that the karst aquifer has a large storage capacity and the drainage of the aquifer occurs very slow. The recession coefficients of the Gökpınar springs have close values that of karst springs in the Antalya region which are lo- cated in the western part of the Taurid Karst Belt. Based on these it may be concluded that the karst aquifer in the study area has similar hydrogeological properties that of the karst aquifers in the Antalya region.

The waters of the study area are not rich in major ions and total dissolved solids (TDS). TDS concentrations are moderate. The major ions in the waters of the study area are $\mathrm{Ca}^{2+}$ and $\mathrm{HCO}_{3}^{-}$, and all waters are of calcium bicarbonate type. Regarding maximum permissible limits in Turkish Drinking Water Standards all waters are suitable for drinking.

Gökpınar springs (GK-1 and GK-2) are undersaturated for anhydrite, dolomite, gypsum and halite minerals. The same springs are generally undersaturated for dolomite and slightly saturated for calcite. Low yield springs are undersaturated to dolomite, and undersaturated or slightly saturated for aragonite and calcite minerals.

As mentioned before, this study is first hydrogeological investigation concerning Gökpınar karst springs. More detailed investigations have to be carried out to determine the age, origin, recharge area and detailed hydrochemistry of the groundwater in the karst aquifer. For this purpose several different investigation methods must be used, including stable and radioactive isotope analyses together with inorganic geochemistry.

\section{ACKNOWLEDGEMENT}

This investigation was financially supported as research project by the Research Found of the Cumhuriyet University, Sivas, Turkey (Project code M-062).

\section{REFERENCES}

Amit, A., Lyakhovsky, V., Katz, A., Starinsky, A. \& A. Burg, 2002: Interpretation of spring recession curves.- Groundwater, 40, 5, 543-551.

Appelo, C.A.J. \& D. Postma, 1996: Gechemistry, Groundwater and Pollution.- Balkema, pp. 536, Rotterdam.

APHA-AWWA-WPCF, 1995: Standart methods for the examination of water and wastewater (19 $9^{\text {th }}$ ed.).American Public Health Association, pp. 1140, Washington DC, USA.
Atabey, E., 1993: Gürün otoktonunun stratigrafisi (Gürün-Sarız arası), Doğu Toroslar-GB Sivas (Stratigraphy of the Gürün autochtonous units-The area between Gürün and Sarız, Eastern Torids, SW Turkey).- Türkiye Jeoloji Bült., 36, 99-113.

Atabey, E., 1996: The development of nummulites banks within the compressional tectonically controlled Tertiary basin of Gürün Autochthone, Eastern Taurus, SW Sivas (Turkey).- Turkish J. Earth Sci., 5, 99-108. 
Atabey, E., Bağırsakçı, S., Canpolat, M., Gökkaya, K.Y., Günal, S. \& N. Kılıç, 1994: Gürün, Kangal (Sivas)Darende, Hasançelebi (Malatya) arasının jeolojisi (Geology of the region between Gürün, Kangal (Sivas) and Darende, Hasançelebi (Malatya)).- MTA Derleme, rep. no. 9760, pp. 20.

Back, W., 1996: Hydrochemical facies and groundwater flow patterns in northern part of Atlantic Coastal Plain.- U.S. Geological Survey, Professional Paper 498-A, pp. 42, Reston.

Bonacci, O., 1993: Karst springs hydrographs as indicators of karst aquifers.- Hydrol. Sci. J, 38, 1-2, 5162.

Bonacci, O., 2001: Analysis of the maximum discharge of karst springs.- Hydrogeology Journal, 9, 4, 328338.

Bögli, A, 1980: Karst Hydrology and Physical Speleology.Springer Verlag, pp. 284, Berlin.

Çelik, M. \& M. Afşin, 1996: The evaluation of karstic aquifer recharge from spring hydrographs; Kazanpınar springs (Elmalı polje, Antalya).- Yerbilimleri (Geosound), 28, 35-41.

De Vries, J.J. \& I. Simmers, 2002: Groundwater recharge: an overview of processes and challenges.- Hydrogeology Journal, 10, 5-17.

Drever, J.I., 1997: The Geochemistry of Natural Waters ( $3^{\text {rd }}$ ed.).- Prentice Hall, pp. 436, New Jersey.

Fiorillo, F., 2009: Spring hydrographs as indicator of droughts in a karst environment.- J. Hydrology, 373, 3-4, 290-301, DOI: 10.1016/j.hydrol.2009.04.034.

Ford, D. \& P. Williams, 2007: Karst Hydrogeology and Geomorphology.- John Wiley \& Sons, pp. 562, Chichester.

Günay, G. \& T. Yayan, 1979: Antalya-Kırkgöz Karst Kaynaklarmın Hidrojeolojisi (Hydrogeological Investigation of the Antalya-Kırkgöz Karst Springs).DSİ-UNDP project (Tur/77/015) no. 32, pp. 118, Ankara.

Hendrickx, J.M.H. \& G.R. Walker, 1997: Recharge from precipitation.- In: Simmers, I. (ed.) Recharge of Phereatic Aquifers in (Semi-) Arid Areas. IAH Publ. n. 19, Balkema, pp. 19-111, Rotterdam.

Hem, J.D., 1985: Study and interpretation of the chemical characteristics of natural water.- US Geological Survey, Water Supply Paper, n. 2254, pp. 263, Reston.

Hershey, R.L., Mizell, S.A. \& S. Earman, 2010: Chemical and physical characteristics of springs discharging from regional flow systems of carbonate-rock province of the Great Basin, western United States.- Hydrogeology Journal, 18, 1007-1026.
Hoetzl, H., 1995: Groundwater recharge in an arid karst area (Saudi Arabia).- In: Adar, E.M. \& C. Leibundgut (eds.) Application of Tracers in Arid Zone Hydrology. IAHS Publ., n. 232, pp. 195-207, Oxfordshire, UK.

Jacobson, R.L. \& D. Langmuir, 1974: Controls on the quality variations of some carbonate spring waters.Journal of Hydrology, 23, 247-265.

Kaçaroğlu, F., 1999: Review of groundwater pollution and protection in karst areas.- Water, Air and Soil Pollution, 113, 337-356.

Kaçaroğlu, F., 2001: Gürün-Gökpınar kaynakları ve civarının hidrojeoloji incelemesi (Hydrogeological investigation of the Gürün-Gökpınar springs and their vicinity).- Cumhuriyet Üniversitesi Araştırma Fonu Proje, n. M-062, pp. 29, Sivas.

Kaçaroğlu, F., 2006: Gökpınar karst kaynaklarının (Gürün-Sivas) hidrojeoloji incelemesi (Hydrogeological investigation of the Gökpınar karst springs (Gürün-Sivas)).- Yerbilimleri, 27, 3, 181-194.

Kaçaroğlu, F., Değirmenci, M. \& O. Cerit, 1997: Karstification in Miocene gypsum: An example from Sivas, Turkey.- Environmental Geology, 30, 1-2, 88-97.

Kaçaroğlu, F., Değirmenci, M. \& O. Cerit, 2001:Water quality problems of a gypsiferous watershed: Upper Kizılırmak Basin, Sivas, Turkey.- Water, Air and Soil Pollution, 128, 161-180.

Kovacs, A., Perrochet, P., Kiraly, L. \& P-Y. Jeannin, 2005: A quantitative method for the characterisation of karst aquifers based on spring hydrograph analysis.- Journal of Hydrology, 303, 152-164.

Kurtman, F., 1978: Gürün bölgesinin jeolojik ve tektonik özellikleri (Geology and tectonics of the Gürün region).- MTA Dergisi, 91, 1-12.

LaFleur, R., 1999: Geomorphic aspects of groundwater flow.- Hydrogeology Journal, 7, 78-93.

Lerner, D., 1997: Groundwater recharge.- In: Saether, O.M. \& P. De Caritat, (eds.) Geochemical Processes, Weathering and Groundwater Recharge in Catchments. Balkema, pp. 109-150, Rotterdam.

Lopez-Chicano, M., Bouamama, M., Vallejos, A. \& A. Pulido-Bosch, 2001: Factors which determine the hydrogeochemical behaviour of karstic springs. A case study from the Betic Cordilleras, Spain.- Applied Geochemistry, 16, 1179-1192.

Maillet, E., 1905: Essais d'Hydraulique souterraine et fluviale.- Hermann, pp. 218, Paris.

Milanovic, P.T., 1981: Karst Hydrogeology.- Water Resources Publications, pp. 434, Littleton.

Piper, A.M., 1944: A graphical procedure in the geochemical interpretation of water analyses.- American Geophysical Union Transactions, 25, 914-923. 
Plummer, L.N., Jones, B.F. \& A.H. Truesdell, 1984: WATEQF-A Fortran IV version of WATEQ, A Computer program for calculating chemical equilibria of natural waters.- U.S. Geological Survey, Water Resources Investigation Report 76-13, Reston.

Shuster, E.T. \& W.B. White, 1971: Seasonal fluctuations in the chemistry of limestone springs: A possible means for characterizing carbonate aquifers.- Journal of Hydrology, 14, 93-128.

Smith, R.A., Alexander, R.B. \& K.J. Lanfear, 1993: Stream water quality in the conterminous United Statesstatus and trends of selected indicators during the 1980's.- In: Paulson, R.W., Chase, E.B., Williams, J.S. \& Moody, D.W. (comps.) National water summary 1990-91- Hydrologic events and stream water quality. U.S. Geological Survey, Water Supply Paper 2400, pp. 111-140, Reston..

TSE, 2005: TS 266 Sular-İnsani Tüketim Amaçlı Sular (TS 266 Water intended for human consumption).Türk Standartları Enstitüsü (Turkish Standards Institution), pp. 10, Ankara.
White, B., 1977: Role of solution kinetics in the development of karst aquifers.- In: Tolson, J.S. \& F.L. Boyle (eds.) Karst Hydrogeology. Int. Assoc. Hydrogeol. Mem., 12, pp. 503-517.

White, W.B., 1999: Groundwater flow in karst aquifers.In: J.W. Delleur (ed.) The Handbook of Groundwater Engineering. CRC Press, chapter 18, 18/1-18/36, Boca Raton.

White, W.B., 2002: Karst hydrology: recent developments and open questions.- Engineering Geology, $65,85-105$.

Yevjevich, V., 1985: Specificities of karst water resources.- In: Günay, G. \& A.I. Johnson (eds.) Karst Water Resources, Proceedings of the Ankara-Antalya Symposium, $8^{\text {th }}-12^{\text {th }}$ July 1985 , Ankara. IAHS Publ., n. 161, 3-20, Ankara. 